\title{
Spirochaeta cellobiosiphila sp. nov., a facultatively anaerobic, marine spirochaete
}

Correspondence John A. Breznak breznak@msu.edu

\author{
John A. Breznak ${ }^{1} \dagger$ and Falk Warnecke ${ }^{2}$
}
${ }^{1}$ Department of Microbiology and Molecular Genetics, Michigan State University, East Lansing, Ml 48824-4320, USA
${ }^{2}$ Microbial Ecology Program, DOE Joint Genome Institute, 2800 Mitchell Drive, Walnut Creek, CA 94598, USA

\begin{abstract}
A facultatively anaerobic, marine spirochaete, designated strain $\mathrm{SIP}^{\top}{ }^{\top}$, was isolated from interstitial water from a cyanobacteria-containing microbial mat. Cells of strain $\operatorname{SIP}^{\top}$ were $0.3-$ $0.4 \times 10-12 \mu \mathrm{m}$ in size, helical with a body pitch of approximately $1.4 \mu \mathrm{m}$ and motile by means of two to four periplasmic flagella (one, or occasionally two, being inserted near each end of the cell). Cells were catalase-negative and used a variety of monosaccharides and disaccharides and pectin as energy sources, growing especially well on cellobiose. Neither organic acids nor amino acids were utilized as energy sources. One or more amino acids in tryptone and one or more components of yeast extract were required for growth. Growth was observed at $9-37{ }^{\circ} \mathrm{C}$ (optimally at or near $37^{\circ} \mathrm{C}$ ), at initial $\mathrm{pH} 5-8$ (optimally at initial $\mathrm{pH} 7.5$ ) and in media prepared with $20-100 \%(\mathrm{v} / \mathrm{v}$ ) seawater (optimally at $60-80 \%$ ) or $0.10-1.00 \mathrm{M} \mathrm{NaCl}$ (optimally at $0.30-$ $0.40 \mathrm{M}$ ). The products of cellobiose fermentation were acetate, ethanol, $\mathrm{CO}_{2}, \mathrm{H}_{2}$ and small amounts of formate. Aerated cultures performed incomplete oxidation of cellobiose to acetate (and, presumably, $\mathrm{CO}_{2}$ ) plus small amounts of ethanol and formate, but exhibited a $Y_{\text {cellobiose }}$ that was only slightly greater than that of cellobiose-fermenting anoxic cultures. The $\mathrm{G}+\mathrm{C}$ content of the genomic DNA of strain SIP1 ${ }^{\top}$ was $41.4 \mathrm{~mol} \%$, the lowest among known spirochaetas. On the basis of its $16 \mathrm{~S}$ rRNA gene sequence, strain $\mathrm{SIP}^{\top}$ was grouped among other members of the genus Spirochaeta, but it bore only $89 \%$ similarity with respect to its closest known relatives,

Spirochaeta litoralis and Spirochaeta isovalerica, two marine obligate anaerobes. On the basis of its phenotypic properties and phylogenetic position, strain SIP1 ${ }^{\top}$ represents a novel species of the genus Spirochaeta, for which the name Spirochaeta cellobiosiphila sp. nov. is proposed. The type strain is $\operatorname{SIP}^{\top}\left(=\right.$ ATCC BAA-1285 ${ }^{\top}=$ DSM $\left.17781^{\top}\right)$.
\end{abstract}

The genus Spirochaeta consists of more than a dozen species of obligately or facultatively anaerobic, saccharolytic, generally free-living spirochaetes found in aquatic habitats. Included are freshwater, marine and halophilic species, as well as alkaliphiles and thermophiles (CanaleParola, 1984, 1992; Aksinova et al., 1992; Hoover et al., 2003; and references therein). Although most known spirochaetas are coiled or undulate in shape and are motile by means of periplasmic flagella, non-motile coccoid types have also been recognized as free-living forms (Ritalahti \& Löffler, 2002, 2003, 2004) and as symbionts in the hindguts

†Present address: 15221 E. Ridgeway Drive, Fountain Hills, AZ 85268, USA.

The GenBank/EMBL/DDBJ accession number for the 16S rRNA gene sequence of strain $\mathrm{SIP}^{\top}{ }^{\top}$ is EU448140.

Details of the dataset used for the construction of the maximumlikelihood phylogenetic tree based on 16S rRNA gene sequences are available as supplementary material with the online version of this paper. of termites (Dröge et al., 2006) and in the excretory organ of a Nautilus species (Pernice et al., 2007).

During the Microbial Diversity Summer Course at the Marine Biological Laboratory, Woods Hole (MA, USA) in 2004, selective isolation of marine spirochaetas was included as a laboratory exercise. This process was performed using serial dilution of inocula in anoxic, rifampicin-containing agar medium (Weber \& Greenberg, 1981), as well as a technique involving placement of filter discs on agar plates (Canale-Parola, 1973). Inasmuch as all known marine spirochaetas were obligate anaerobes, special attention was paid to the possible development of spirochaete colonies on plates of a non-reduced isolation medium incubated in air, in that such colonies might represent novel organisms. Such colonies appeared and a facultatively anaerobic, marine member of the genus Spirochaeta was isolated that was sufficiently different from other members of the genus to be considered as representing a novel species. This paper describes the 
isolation and properties of this strain, which was designated SIP $1^{\mathrm{T}}$.

Isolation was performed on plates containing SCTY isolation medium [comprising, $1^{-1}: 700 \mathrm{ml}$ seawater, $2.0 \mathrm{~g}$ cellobiose, $2.0 \mathrm{~g}$ tryptone (Difco), $1.0 \mathrm{~g}$ yeast extract (Difco), $10.0 \mathrm{~g}$ agar (Difco) and $300 \mathrm{ml}$ distilled water] adjusted to $\mathrm{pH} 7.5$ prior to autoclaving. Four sterile filter discs (mixed esters of cellulose; $0.45 \mu \mathrm{m}$ mean pore diameter; Millipore) were placed on each plate and the centre of each disc was inoculated with approximately $0.5 \mathrm{ml}$ marine sample. Plates were incubated (filter side up) for $8 \mathrm{~h}$ in air at $30{ }^{\circ} \mathrm{C}$, after which the filter discs were removed aseptically; the plates were then turned upside down and incubated again. After 5 days, subsurface, semitransparent, pale-yellow and white spreading colonies were observed on a plate inoculated with water that had been expressed, by gentle pressure, from a portion of a cyanobacteria-containing microbial mat collected from Little Sippewissett salt marsh, Woods Hole (MA, USA). Phase-contrast microscopy of a thin slice of agar from the advancing margin of a pale-yellow subsurface colony revealed cells with spirochaete-like morphology and motility; similar samples from the white colonies revealed thin, rapidly motile rods. Additional samples from the pale-yellow colony were excised, macerated on the surfaces of fresh plates and streaked for the purposes of isolation. After three successive subcultures had been performed using well-isolated colonies (each being composed of spirochaetes possessing uniform cell morphology), the culture was considered pure and was designated strain $\operatorname{SIP} 1^{\mathrm{T}}$. Analogous isolation plates inoculated with surficial sediment water from Eel Pond, Oyster Pond Inlet and the Great Sippewissett salt marsh (all at Woods Hole) did not yield spirochaete colonies.

Strain $\operatorname{SIP} 1^{\mathrm{T}}$ was routinely maintained at room temperature $\left(22-23{ }^{\circ} \mathrm{C}\right)$, under air, in $15 \mathrm{~mm}$ screw-capped tubes approximately two-thirds full with SCTY broth (as above, but lacking agar) or CTY broth. CTY broth contained the following $\left(1^{-1}\right): 2.0 \mathrm{~g}$ each of cellobiose and tryptone, $1.0 \mathrm{~g}$ yeast extract, $20.45 \mathrm{~g} \mathrm{NaCl}$ (equivalent to $0.35 \mathrm{M}$ ); $0.52 \mathrm{~g}$ $\mathrm{KCl}, 4.31 \mathrm{~g} \mathrm{MgSO}_{4} \cdot 7 \mathrm{H}_{2} \mathrm{O}, 3.56 \mathrm{~g} \mathrm{MgCl}_{2} \cdot 6 \mathrm{H}_{2} \mathrm{O}, 0.18 \mathrm{~g}$ $\mathrm{K}_{2} \mathrm{HPO}_{4}, 2.38 \mathrm{~g}$ HEPES buffer and $1.03 \mathrm{~g} \mathrm{CaCl}_{2} .2 \mathrm{H}_{2} \mathrm{O}$. All of the ingredients in CTY medium (except $\mathrm{CaCl}_{2} \cdot 2 \mathrm{H}_{2} \mathrm{O}$ ) were dissolved in $990 \mathrm{ml}$ distilled water and the solution was adjusted to $\mathrm{pH} 7.5$ prior to being sterilized by autoclaving. When cooled, $10 \mathrm{ml}\left(1^{-1}\right) 100 \times$ sterile stock solution of $\mathrm{CaCl}_{2} \cdot 2 \mathrm{H}_{2} \mathrm{O}$ (i.e. $102.9 \mathrm{~g} \mathrm{l}^{-1}$ ) was added. The final $\mathrm{pH}$ of the CTY medium was 7.3-7.4. Routine subculture was achieved by means of loop transfer every 3-4 days. Growth studies designed to determine the physiological properties and nutritional requirements of cells were performed using $10 \mathrm{ml}$ medium in $18 \mathrm{~mm}$ diameter tubes incubated upright, in air, without shaking. Inocula $(0.1 \%, \mathrm{v} / \mathrm{v})$ usually consisted of cells growing in CTY medium at room temperature. Salt requirements and salt tolerance were evaluated by using SCTY broth or CTY broth and varying the seawater or $\mathrm{NaCl}$ content in $10 \%$ (v/ v) or $0.10 \mathrm{M}$ increments, respectively. The $\mathrm{pH}$ optimum and range were determined by adjusting CTY broth to various initial $\mathrm{pH}$ values and filter-sterilizing the medium prior to inoculation. Nutritional requirements were evaluated by using CTY broth in which cellobiose, tryptone or yeast extract were omitted or replaced with other compounds. Growth was quantified by determining the $\mathrm{OD}_{600}$ with a Spectronic 20 colorimeter (Bausch \& Lomb) and the readings were converted into cell number, cell protein or cell dry mass equivalents by using standard curves correlating these quantities (Graber et al., 2004). Aerated (oxic) cultures were grown in Erlenmeyer flasks (each equipped with a side arm allowing $\mathrm{OD}_{600}$ readings to be taken) one-fifth filled with medium; the flasks were shaken on a rotary shaker operating at 120 r.p.m. Anoxic cultures were grown in $18 \mathrm{~mm}$ anaerobe tubes (or in bottles each fitted with an $18 \mathrm{~mm}$ anaerobe tube as a side arm) sealed under $\mathrm{N}_{2}$ with butyl rubber stoppers as described previously (Wertz \& Breznak, 2007). Soluble metabolic products were determined by means of HPLC with refractive index and UV detection, while $\mathrm{H}_{2}$ was determined by GC; both procedures were performed as described previously (Graber et al., 2004). $\mathrm{CO}_{2}$ was determined gravimetrically (Breznak \& Canale-Parola, 1969). HPLC determination of the $\mathrm{G}+\mathrm{C}$ content of genomic DNA and phase-contrast photomicroscopy were performed as described previously (Graber et al., 2004; Wertz \& Breznak, 2007). Transmission electron micrographs were prepared from cells negatively stained with $1 \%$ ammonium molybdate and examined with a JEOL JEM100C XII electron microscope operating at an accelerating voltage of $100 \mathrm{kV}$.

Cells of strain SIP $1^{\mathrm{T}}$ were $0.3-0.4 \mu \mathrm{m}$ in diameter and $10-$ $12 \mu \mathrm{m}$ long (range, 5-40 $\mu \mathrm{m}$ ) with slightly tapered ends (Fig. 1a, c); they appeared to be helical, with a mean body pitch of approximately $1.4 \mu \mathrm{m}$ (as measured from phasecontrast micrographs). Cells also possessed ultrastructural features typical of most known spirochaetes, including the following: a protoplasmic cylinder; two to four periplasmic flagella (one, occasionally two, being inserted near each end of the protoplasmic cylinder); and an outer membranous sheath (Fig. 1b). Cells were motile, with spinning and flexing movements, and gave rise to spherical bodies (Breznak \& Canale-Parola, 1975) that were either free or attached to the spiral cells and which became more numerous when cells entered stationary phase and as cultures aged and lost viability.

In SCTY medium, strain SIP $1^{\mathrm{T}}$ grew best if seawater comprised $60-80 \%(\mathrm{v} / \mathrm{v}$; balance, distilled water) of the liquid phase (range, $20-100 \%$ seawater). In CTY medium, cells grew best with $0.30-0.40 \mathrm{M} \mathrm{NaCl}$ (range, 0.10$1.00 \mathrm{M}$ ), at initial $\mathrm{pH} 7.5$ (range, $\mathrm{pH} 5.0-8.0$ ) and at, or near, $37{ }^{\circ} \mathrm{C}$ (range, $9-37{ }^{\circ} \mathrm{C}$ ). No growth was observed at $42{ }^{\circ} \mathrm{C}$. Under optimum conditions, the doubling time $\left(t_{\mathrm{d}}\right)$ of cells in unshaken tubes of CTY medium under air was $1.9 \mathrm{~h}$ (mean of two determinations). At $30^{\circ} \mathrm{C}$ (the temperature used for most experiments), cells grew only 


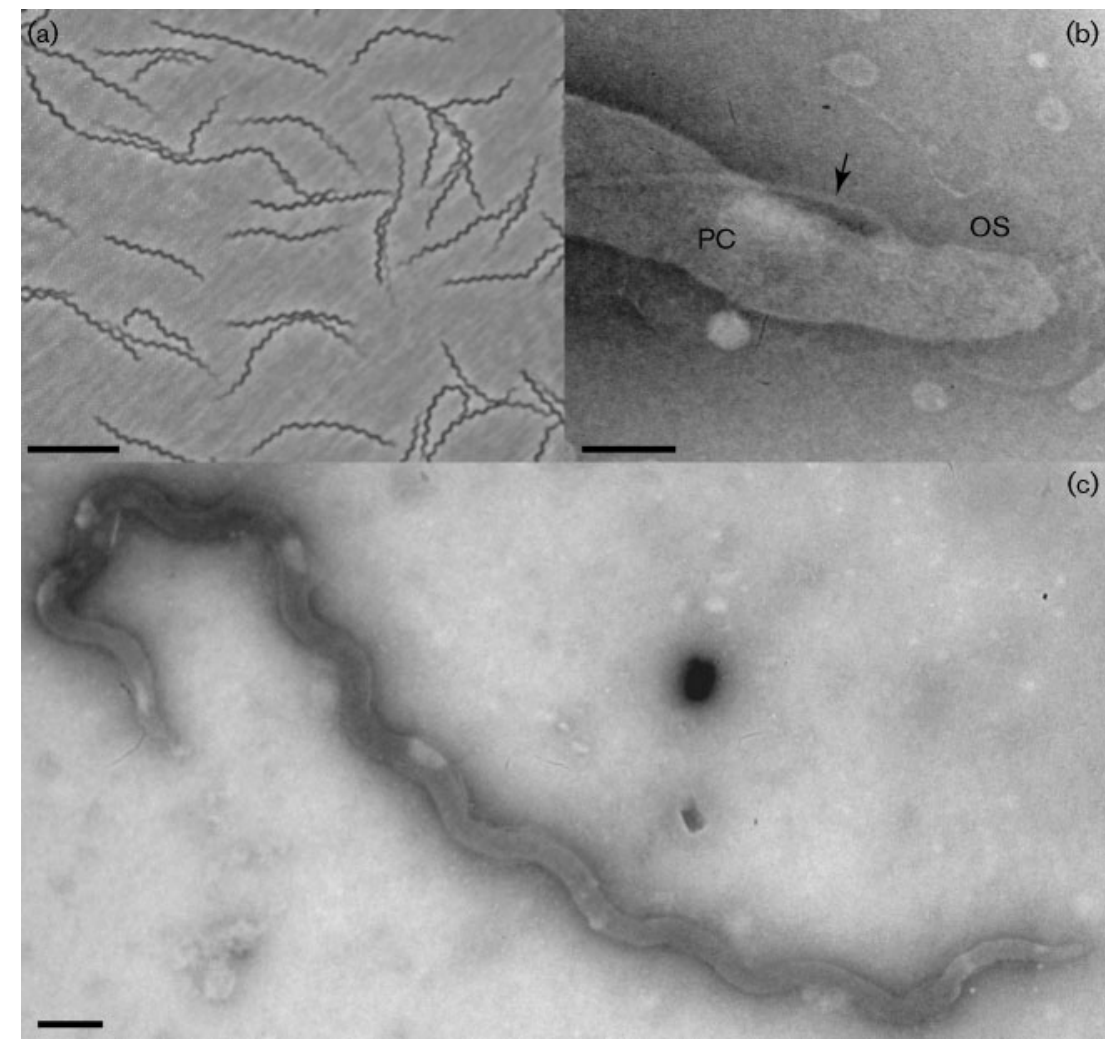

Fig. 1. Micrographs of cells of strain $\mathrm{SIP}^{\top}$. (a) Phase-contrast micrographs of cells in late exponential phase. (b, c) Transmission electron micrographs of cells negatively stained with $1 \%$ ammonium molybdate. The arrow in (b) indicates a periplasmic flagellum inserted subterminally into the protoplasmic cylinder (PC); OS, outer sheath. Bars, $10 \mu \mathrm{m}$ (a), $0.2 \mu \mathrm{m}(\mathrm{b})$ and $1.0 \mu \mathrm{m}$ (c).

slightly more slowly, whether in unshaken tubes $\left(t_{\mathrm{d}}=2.2 \pm 0.2 \mathrm{~h}\right.$; mean $\pm \mathrm{SD}$ for four determinations $)$ or in shake flasks ( $t_{\mathrm{d}}=2.1 \mathrm{~h}$; mean of two determinations). Cells of strain SIP $1^{\mathrm{T}}$ harvested from aerated cultures in CTY medium were catalase-negative and pale yellow in colour, but gave a negative reaction in the carotenoid spot test (Breznak \& Canale-Parola, 1969). Likewise, acetone/ methanol $(70: 30, \mathrm{v} / \mathrm{v})$ extracts of cell pellets did not possess a visible wavelength spectrum typical of that of carotenoids (Zechmeister, 1962; data not shown). The $\mathrm{NaCl}$ requirement for optimum growth of strain $\mathrm{SIP} 1^{\mathrm{T}}$ was similar to that for other mesophilic, neutrophilic, marine spirochaetas, e.g. Spirochaeta litoralis, Spirochaeta isovalerica and Spirochaeta bajacaliforniensis, all of which are obligate anaerobes, but it was about half that required for optimum growth of Spirochaeta halophila, a carotenoidpigmented, facultative anaerobe isolated from a highsalinity pond, and Spirochaeta smaragdinae, an obligate anaerobe isolated from an offshore oilfield (Table 1). In contrast, the facultatively anaerobic, freshwater spirochaete Spirochaeta aurantia subsp. aurantia $\mathrm{J1}^{\mathrm{T}}$ (=ATCC $25082^{\mathrm{T}}$; Breznak \& Canale-Parola, 1969), used here as a control, grew best in CTY medium with no added $\mathrm{NaCl}$ (range, 0 $0.10 \mathrm{M} \mathrm{NaCl}$ ). Similar results were reported previously for $S$. aurantia, as well as for the freshwater, anaerobic spirochaete Spirochaeta stenostrepta (Hespell \& CanaleParola, 1970).

The yields of strain $\mathrm{SIP} 1^{\mathrm{T}}$ in tubes of CTY medium were 5$7 \times 10^{8}$ cells $\mathrm{ml}^{-1}$. In CTY medium lacking tryptone, the cell yields were only about $25 \%$ of that normally attained, whether or not $5 \mathrm{mM} \mathrm{NH}_{4} \mathrm{Cl}$ was included in the medium. The cell yields in CTY medium lacking yeast extract were only about $10 \%$ of that normally attained; little or no growth was observed in CTY medium lacking cellobiose. These results implied that cellobiose was used as a primary energy source by strain $\operatorname{SIP} 1^{\mathrm{T}}$ and that one or more of the amino acids in tryptone was required for growth, as was one or more components present in yeast extract. Cellobiose, when present at $5 \mathrm{mM}$ in static culture tubes of CTY medium at $30{ }^{\circ} \mathrm{C}$, supported a doubling time of $2.2 \mathrm{~h}$. A variety of other monosaccharides and disaccharides (tested at 10 and $5 \mathrm{mM}$, respectively), as well as pectin (Sigma-Aldrich; tested at $0.2 \%, \mathrm{w} / \mathrm{v}$ ), were also used as energy sources by strain $\operatorname{SIP} 1^{\mathrm{T}}$, but the doubling times at $30{ }^{\circ} \mathrm{C}$ were substantially longer than those obtained with cellobiose, e.g. glucose, $4.5 \mathrm{~h}$; galactose, $5.2 \mathrm{~h}$; D-xylose, $7.4 \mathrm{~h}$; L-arabinose, $7.4 \mathrm{~h}$; sucrose, $17.0 \mathrm{~h}$; mannose, $17.8 \mathrm{~h}$; trehalose, $18.8 \mathrm{~h}$; maltose, $19.2 \mathrm{~h}$; and pectin, $162.0 \mathrm{~h}$. Little or no growth above that of 'no cellobiose' controls occurred with fructose, L-fucose, L-rhamnose, mannitol, Dribose, arabinoxylan $(0.2 \%, \mathrm{w} / \mathrm{v}$; Megazyme), cellulose $(0.5 \times 2 \mathrm{~cm}$ strip of Whatman No. 4 filter paper), acetate, lactate, citrate or succinate (organic acids added as sodium salts, $5.0 \mathrm{mM}$ final concentration; tested under both anoxic and aerated culture conditions). Hence, strain SIP $1^{\mathrm{T}}$ was typical of most other known spirochaetas in being saccharolytic and unable to use organic acids or amino acids as energy sources for growth. The ability of strain 
Table 1. Characteristics of strain $\mathrm{SIP}^{\top}{ }^{\top}$ that serve to distinguish it from mesophilic, neutrophilic, marine and halophilic spirochaetas

Strains: $1, \operatorname{SIP}^{\mathrm{T}}$ (data from this study); 2, S. litoralis $\mathrm{R}^{\mathrm{T}}$ (Hespell \& Canale-Parola, 1970); 3, S. isovalerica MA-2 ${ }^{\mathrm{T}}$ (Harwood \& Canale-Parola, 1983); 4, S. bajacaliforniensis BA-2 ${ }^{\mathrm{T}}$ (Fracek \& Stolz, 1985); 5, S. halophila RS1 ${ }^{\mathrm{T}}$ (Greenberg \& Canale-Parola, 1976); 6, S. smaragdinae SEBR 4228 ${ }^{\mathrm{T}}$ (Magot et al., 1997). All strains produce acetate, ethanol, $\mathrm{H}_{2}$ and $\mathrm{CO}_{2}$ as major products of carbohydrate fermentation. + , Substrate used as an energy source; -, substrate not used.

\begin{tabular}{|c|c|c|c|c|c|c|}
\hline Characteristic & 1 & 2 & 3 & 4 & 5 & 6 \\
\hline Cell size $(\mu \mathrm{m})$ & $0.3-0.4 \times 10-12$ & $0.4-0.5 \times 6-7$ & $0.4 \times 10-15$ & $0.3 \times 30$ & $0.4 \times 15-30$ & $0.3-0.5 \times 5-30$ \\
\hline \multicolumn{7}{|l|}{ Optimum growth conditions } \\
\hline $\mathrm{pH}$ & 7.5 & $7.0-7.5$ & NR & 7.5 & 7.5 & $7.0-7.2$ \\
\hline Temperature $\left({ }^{\circ} \mathrm{C}\right)$ & $30-37$ & 30 & 30 & 36 & $35-40$ & 37 \\
\hline \multicolumn{7}{|l|}{ Substrate utilization } \\
\hline L-Rhamnose & - & + & + & + & + & - \\
\hline Fructose & - & + & + & + & + & + \\
\hline Mannose & + & + & + & - & + & + \\
\hline D-Xylose & + & + & + & - & + & + \\
\hline $\mathrm{O}_{2}$ metabolism ${ }^{*}$ & $\mathrm{FA}$ & $\mathrm{OA}$ & $\mathrm{OA}$ & $\mathrm{OA}$ & FA & $\mathrm{OA}$ \\
\hline DNA G $+C$ content $(\mathrm{mol} \%)$ & 41.4 & $50.5^{a}, 44.2^{b} \dagger$ & $63.6-65.6$ & 50.1 & 62 & 50 \\
\hline
\end{tabular}

${ }^{*} \mathrm{FA}$, Facultative anaerobe; OA, obligate anaerobe.

$\nmid$ Results obtained using the buoyant density method by Hespell \& Canale-Parola (1970) (a) and using the $T_{\mathrm{m}}$ method by Breznak \& Canale-Parola (1975) (b).

SIP $1^{\mathrm{T}}$ to use amino acids such as L-leucine, L-isoleucine and L-valine as energy sources for maintenance and survival (but not growth), as demonstrated by $S$. isovalerica (Harwood \& Canale-Parola, 1983), was not explored. However, no branched-chain fatty acids resulting from the metabolism of such amino acids were detected in cellobiose-limited anoxic or aerated cultures (below).

Products formed during anoxic growth of strain $\operatorname{SIP}^{\mathrm{T}}$ in CTY medium containing cellobiose at $2.5 \mathrm{mM}$ (a concentration determined empirically to be growth-limiting for both anoxic and aerated cultures) were as follows (mol per 100 mol glucosyl unit of cellobiose): acetate, 80.1; ethanol, 69.4; $\mathrm{CO}_{2}, 152.3 ; \mathrm{H}_{2}, 183.7$; and formate, 29.9 (carbon recovery $80.2 \%$; oxidation/reduction index 1.04 ). These fermentation products are among those typically produced by spirochaetes of the genus Spirochaeta (Canale-Parola, 1984, 1992; Hoover et al., 2003 and references therein; Dröge et al., 2006). No other soluble or gaseous products were detected by HPLC or GC, respectively. These results imply that nearly $20 \%$ of the cellobiose carbon may have been assimilated by the cells. This degree of assimilation, although apparently high for the conditions employed (i.e. during energy-source-limited anoxic growth of cells in a complex medium), is nevertheless similar to that of maltose-carbon assimilation by $S$. aurantia during anoxic growth under comparable conditions (16.1-17.5\%; Breznak \& Canale-Parola, 1972). Soluble products formed by strain $\mathrm{SIP}^{\mathrm{T}}$ during aerobic growth on $2.5 \mathrm{mM}$ cellobiose were as follows (mol per $100 \mathrm{~mol}$ glucosyl unit): acetate, 122.4; ethanol, 11.0; and formate, 2.9. These results suggest that strain $\operatorname{SIP} 1^{\mathrm{T}}$, like aerated cultures of $S$. aurantia (Breznak \& Canale-Parola, 1972) and S. halophila (Greenberg \& Canale-Parola, 1976), uses oxygen as an electron acceptor to perform incomplete oxidation of carbohydrate, mainly to acetate (and presumably $\mathrm{CO}_{2}$, which was not measured). Consistent with this interpretation was the observation that strain $\operatorname{SIP} 1^{\mathrm{T}}$, like S. aurantia and S. halophila, did not use acetate, lactate or tricarboxylic acid cycle intermediates as energy sources for aerobic growth (above), implying that it, too, lacks a complete tricarboxylic acid cycle. However, the $Y_{\text {substrate }}$ values for $S$. aurantia and $S$. halophila grown under aerated conditions were 2- to 3.4-fold greater than those obtained under anoxic conditions, and both of these species appear to be capable of conserving energy by oxidative phosphorylation during incomplete aerobic oxidation of carbohydrates. In

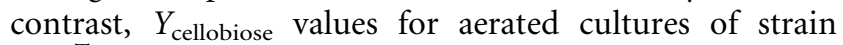
$\mathrm{SIP}^{\mathrm{T}}$ (approx. $98.3 \mathrm{~g}$ dry mass per mol cellobiose) were only 1.2 -fold greater than those for anoxic cultures (approx. $79.2 \mathrm{~g}$ dry mass per mol cellobiose). This may simply reflect a modest gain in net ATP yield from substrate-level phosphorylation (via the acetate kinase reaction) accompanying the incremental increase in acetate produced (per mol cellobiose) under aerated conditions, rather than a genuine capacity for oxidative phosphorylation. Nevertheless, even modest gains in energy resulting from the presence of oxygen may be of competitive or survival value to strain SIP1 ${ }^{\mathrm{T}}$ in situ and could be obtained, in part, during oxygenic photosynthesis of cyanobacteria and algae in the salt-marsh microbial mats it inhabits.

The 16S rRNA gene of strain SIP1 $1^{\mathrm{T}}$ was amplified by using a PCR with primers 27F (5'-AGAGTTTGATCCTGGC- 
TCAG-3') and 1492R (5'-GGTTACCTTGTTACGACTT$3^{\prime}$ ) and then subjected to bidirectional sequencing of the amplicon. Sequencing reads were assembled using SEQUENCHER software, resulting in a $1435 \mathrm{bp}$ contiguous sequence. Each region of the sequence was covered by at least four individual sequencing reads. Because the PCR product was sequenced directly (i.e. without cloning), the sequence obtained may be a composite sequence from multiple 16S rRNA genes present in the SIP1 ${ }^{\mathrm{T}}$ genome. Phylogenetic analysis was performed using the software package ARB (Ludwig et al., 2004) and the greengenes database (DeSantis et al., 2006). The closest relatives of strain SIP $1^{\mathrm{T}}$ were determined by using the ARB PT server and the greengenes classification tool SIMRANK, as well as by means of a BLAST search. After manual sequence alignment curation, a dataset of 130 sequences (see Supplementary Table S1 for accession numbers) was compiled and a maximum-likelihood tree was calculated and bootstrapped using the RAxML algorithm (Stamatakis et al., 2005); highly variable regions of the $16 \mathrm{~S}$ rRNA were excluded (lanemaskPH, i.e. 1241 positions were considered). The resulting tree is shown in Fig. 2; for clarity, not all 130 sequences are included. However, the similarity values reported in the text (rounded to the nearest whole per cent) were taken from a matrix table whose calculation did include the highly variable regions of the $16 \mathrm{~S}$ rRNA. It should be noted that S. stenostrepta, Spirochaeta zuelzerae and Spirochaeta caldaria are not shown in Fig. 2. These species were named before their 16S rRNA gene sequences were available and were classified as belonging to the genus Spirochaeta partly because of their putatively free-living existence. However, they are now known to be more closely related to members of the genus Treponema, whose members are largely associated with animal hosts (Paster et al., 1991).

The results of this study indicate that strain SIP $1^{\mathrm{T}}$ is readily distinguishable from recognized spirochaetas on the basis of physiological and nutritional properties, as well as from the $\mathrm{G}+\mathrm{C}$ content of its genomic DNA, which is the lowest among known spirochaetas (Table 1; Canale-Parola, 1984, 1992; Aksinova et al., 1992; Hoover et al., 2003; Dröge et al., 2006; and references therein). Moreover, the 16S rRNA gene sequence of strain SIP $1^{\mathrm{T}}$ is phylogenetically distinct from those of all recognized spirochaetas (Fig. 2) and bears only $89 \%$ similarity with the sequences of its closest known relatives, S. litoralis and S. isovalerica. While such low levels of similarity might prompt the proposal of a novel genus for strain $\mathrm{SIP1}^{\mathrm{T}}$, not merely a novel species, there are several reasons why this is not advisable. Doing so would imply that other species within the tree shown in Fig. 2 should also be assigned to a novel genus/genera, as the mean similarity of all Spirochaeta strains and clones depicted in Fig. 2 is only $86 \pm 3 \%$ (mean \pm SD), the lowest similarity among named species $(81 \%)$ occurring between S. litoralis and Spirochaeta coccoides. Even among the freeliving neutrophilic marine and halophilic spirochaetas (Table 1 ), the mean interspecies similarity is only $88 \pm 3 \%$. Moreover, if such reassignment were contemplated it would still be difficult to decide which species should correctly remain in the genus Spirochaeta, as no $16 \mathrm{~S}$ rRNA gene sequence is available for the uncultured species Spirochaeta plicatilis, the type species of the genus (CanaleParola, 1984).

Clearly, the genus Spirochaeta is a good candidate for revision, an effort that would be best achieved by using a comprehensive polyphasic taxonomic approach facilitated by the acquisition of $16 \mathrm{~S}$ rRNA gene sequence data for the type species, S. plicatilis. However, that is beyond the scope of the present communication. Accordingly, and until any such future revision dictates otherwise, strain SIP $1^{\mathrm{T}}$ represents a novel species of the genus Spirochaeta, for which the name Spirochaeta cellobiosiphila sp. nov. is proposed.

\section{Description of Spirochaeta cellobiosiphila sp. nov.}

Spirochaeta cellobiosiphila (cel.lo.bi.o.si'phi.la. N.L. neut. n. cellobiosum cellobiose; N.L. fem. adj. phila from Gr. fem.

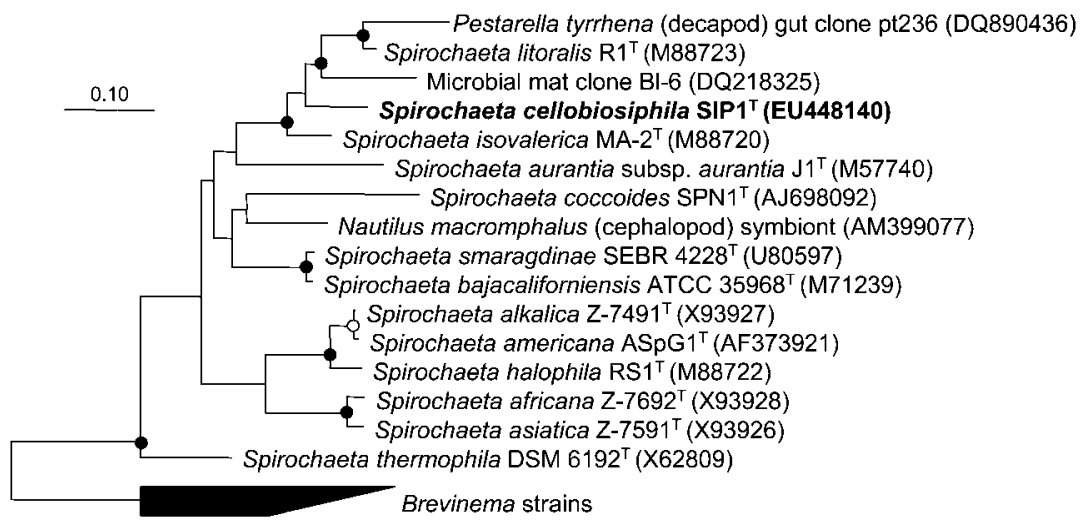

Fig. 2. Maximum-likelihood phylogenetic tree, based on 16S rRNA gene sequences, for strain $S I P 1^{\top}$. Bootstrap percentages are shown at nodes, as follows: filled circles, 75$100 \%$; open circles, 50-74\%. GenBank accession numbers are shown in parentheses. The black shape at the bottom represents the phylogenetic breadth and depth of 16S rRNA gene sequences from selected Brevinema andersonii strains (GenBank accession numbers M59179.1, L31544.1 and L31543.1) and Brevinema environmental clones (DQ340184.1 and AF027047.1), which were used collectively as an outgroup. Bar, 10\% estimated sequence divergence. 
adj. philê friendly to, loving; N.L. fem. adj. cellobiosiphila loving cellobiose).

Cells are pale yellow, $0.3-0.4 \times 10-12 \mu \mathrm{m}$ in size and helical, with a body pitch of $1.4 \mu \mathrm{m}$. Motile by means of two (occasionally four) periplasmic flagella, of which one (or two) is inserted near each end of the cell. Facultatively anaerobic and catalase-negative. Growth occurs at $9-37{ }^{\circ} \mathrm{C}$ (optimally at or near $37^{\circ} \mathrm{C}$ ), at initial pH 5-8 (optimally at initial $\mathrm{pH} 7.5)$ and in media prepared with $20-100 \%(\mathrm{v} / \mathrm{v})$ seawater (optimally at 60-80\%) or containing 0.10 $1.00 \mathrm{M} \mathrm{NaCl}$ (optimally at $0.30-0.40 \mathrm{M}$ ). A variety of monosaccharides and disaccharides and pectin (but not cellulose or arabinoxylan) are used as energy sources; the most rapid growth occurs on cellobiose. Neither organic acids nor amino acids are utilized as energy sources. One or more amino acids in tryptone and one or more components of yeast extract are required for growth. The products of cellobiose fermentation are acetate, ethanol, $\mathrm{CO}_{2}, \mathrm{H}_{2}$ and small amounts of formate. Aerated cultures oxidize cellobiose incompletely to acetate (and, presumably, $\mathrm{CO}_{2}$ ) plus small amounts of ethanol and formate; they exhibit a $Y_{\text {cellobiose }}$ that is 1.2 -fold greater than that of cellobiose-fermenting cultures. The $\mathrm{G}+\mathrm{C}$ content of the genomic DNA of the type strain is $41.4 \mathrm{~mol} \%$ (HPLC).

The type strain, SIP $1^{\mathrm{T}} \quad\left(=\mathrm{ATCC}\right.$ BAA- $1285^{\mathrm{T}}=\mathrm{DSM}$ $\left.17781^{\mathrm{T}}\right)$, was isolated from interstitial water of a cyanobacteria-containing microbial mat collected from Little Sippewissett salt marsh, Woods Hole, MA, USA.

\section{Acknowledgements}

Portions of this work were done during the 2004 Microbial Diversity Summer Course at the Marine Biological Laboratory, Woods Hole (MA, USA) co-directed by T. M. Schmidt and W. W. Metcalf and funded by grants from the NSF (0415401), the DOE (DE-FG0285ER13361) and the Gordon and Betty Moore Foundation. We thank J. Waterbury (Woods Hole Oceanographic Institution) for providing a portion of the microbial mat from which strain SIP $1^{\mathrm{T}}$ was isolated, J. McKinlay for performing some of the HPLC analyses of metabolic products, S. Eichorst and J. Wertz for analysing the DNA G $+\mathrm{C}$ content, A. Pastor (Michigan State University Center for Advanced Microscopy) for performing electron microscopy and Professor Dr H. G. Trüper for help with the nomenclature and Latinization of the species name.

\section{References}

Aksinova, H. Y., Rainey, F. A., Janssen, P. H., Zavarzin, G. A. \& Morgan, H. W. (1992). Spirochaeta thermophila sp. nov., an obligately anaerobic, polysaccharolytic, extremely thermophilic bacterium. Int $J$ Syst Bacteriol 42, 175-177.

Breznak, J. A. \& Canale-Parola, E. (1969). Spirochaeta aurantia, a pigmented, facultatively anaerobic spirochete. J Bacteriol 97, 386-395.

Breznak, J. A. \& Canale-Parola, E. (1972). Metabolism of Spirochaeta aurantia. II. Aerobic oxidation of carbohydrates. Arch Microbiol 83, 278-292.

Breznak, J. A. \& Canale-Parola, E. (1975). Morphology and physiology of Spirochaeta aurantia strains isolated from aquatic habitats. Arch Microbiol 105, 1-12.
Canale-Parola, E. (1973). Isolation, growth and maintenance of anaerobic free-living spirochetes. Methods Microbiol 8, 61-73.

Canale-Parola, E. (1984). Genus I. Spirochaeta Ehrenberg 1835, $313^{\mathrm{AL}}$. In Bergey's Manual of Systematic Bacteriology, vol. 1, pp. 3946. Edited by N. R. Krieg \& J. G. Holt. Baltimore: Williams \& Wilkins.

Canale-Parola, E. (1992). Free-living saccharolytic spirochetes: the genus Spirochaeta. In The Prokaryotes, 2nd edn, pp. 3524-3536. Edited by A. Balows, H. G. Trüper, M. Dworkin, W. Harder \& K. H. Schleifer. New York: Springer.

DeSantis, T. Z., Hugenholtz, P., Larsen, N., Rojas, M., Brodie, E. L., Keller, K., Huber, T., Dalevi, D., Hu, P. \& Andersen, G. L. (2006). Greengenes, a chimera-checked 16S rRNA gene database and workbench compatible with ARB. Appl Environ Microbiol 72, 50695072.

Dröge, S., Fröhlich, J., Radek, R. \& König, H. (2006). Spirochaeta coccoides sp. nov., a novel coccoid spirochete from the hindgut of the termite Neotermes castaneus. Appl Environ Microbiol 72, 392-397.

Fracek, S. P. \& Stolz, J. F. (1985). Spirochaeta bajacaliforniensis sp. n. from a microbial mat community at Laguna Figueroa, Baja California Norte, Mexico. Arch Microbiol 142, 317-325.

Graber, J. R., Leadbetter, J. R. \& Breznak, J. A. (2004). Description of Treponema azotonutricium sp. nov. and Treponema primitia sp. nov., the first spirochetes isolated from termite hindguts. Appl Environ Microbiol 70, 1315-1320.

Greenberg, E. P. \& Canale-Parola, E. (1976). Spirochaeta halophila sp. n., a facultative anaerobe from a high salinity pond. Arch Microbiol 110, 185-194.

Harwood, C. S. \& Canale-Parola, E. (1983). Spirochaeta isovalerica sp. nov., a marine anaerobe that forms branched-chain fatty acids as fermentation products. Int J Syst Bacteriol 33, 573-579.

Hespell, R. B. \& Canale-Parola, E. (1970). Spirochaeta litoralis sp. n., a strictly anaerobic marine spirochete. Arch Microbiol 74, 1-18.

Hoover, R. B., Pikuta, E. V., Bej, A. K., Marsic, D., Whitman, W. B., Tang, J. \& Krader, P. (2003). Spirochaeta americana sp. nov., a new haloalkaliphilic, obligately anaerobic spirochaete isolated from soda Mono Lake in California. Int J Syst Evol Microbiol 53, 815-821.

Ludwig, W., Strunk, O., Westram, R., Richter, L., Meier, H., Yadhukumar, Buchner, A., Lai, T., Steppi, S. \& other authors (2004). ARB: a software environment for sequence data. Nucleic Acids Res 32, 1363-1371.

Magot, M., Fardeau, M.-L., Arnauld, O., Lanau, C., Ollivier, B., Thomas, P. \& Patel, B. K. C. (1997). Spirochaeta smaragdinae sp. nov., a new mesophilic strictly anaerobic spirochete from an oil field. FEMS Microbiol Lett 155, 185-191.

Paster, B. J., Dewhirst, F. E., Weisburg, W. G., Tordoff, L. A., Fraser, G. J., Hespell, R. B., Stanton, T. B., Zablen, L., Mandelco, L. \& Woese, C. R. (1991). Phylogenetic analysis of spirochetes. J Bacteriol 173, 6101-6109.

Pernice, M., Wetzel, S., Gros, O., Boucher-Rodoni, R. \& Dubilier, N. (2007). Enigmatic dual symbiosis in the excretory organ of Nautilus macromphalus (Cephalopoda: Nautiloidea). Proc Biol Sci 274, 11431152.

Ritalahti, K. M. \& Löffler, F. E. (2002). Ecology and characterization of novel, free-living, non-spiral spirochetes. In Abstracts of the 102nd General Meeting of the American Society for Microbiology, Salt Lake City, UT, USA, abstract I-14. Washington, DC: American Society for Microbiology.

Ritalahti, K. M. \& Löffler, F. E. (2003). Non-spiral spirochetes (NSS), sticky denizens in anoxic environments. In Abstracts of the 103rd General Meeting of the American Society for Microbiology, Washington, 
DC, USA, abstract I-133. Washington, DC: American Society for Microbiology.

Ritalahti, K. M. \& Löffler, F. E. (2004). Characterization of novel freeliving pleiomorphic spirochetes (FLiPS). In Abstracts of the 10th International Symposium on Microbial Ecology, Cancun, Mexico, abstract 539. Geneva: International Society for Microbial Ecology.

Stamatakis, A., Ludwig, T. \& Meier, H. (2005). RAxML-III: a fast program for maximum likelihood-based inference of large phylogenetic trees. Bioinformatics 21, 456-463.
Weber, F. H. \& Greenberg, E. P. (1981). Rifampin as a selective agent for the enumeration and isolation of spirochetes from salt marsh habitats. Curr Microbiol 5, 303-306.

Wertz, J. T. \& Breznak, J. A. (2007). Stenoxybacter acetivorans gen. nov., sp. nov., an acetate-oxidizing obligate microaerophile among diverse $\mathrm{O}_{2}$-consuming bacteria from termite guts. Appl Environ Microbiol 73, 6819-6828.

Zechmeister, L. (1962). Cis-trans Isomeric Carotenoids, Vitamins A and Arylpolyenes. Vienna: Springer. 